\title{
An Iron Rod Stuck in the Right Motor Cortex
}

\section{Sağ Motor Kortekse Saplanmış Demir Çubuk}

\author{
Erkin SONMEZ ${ }^{1}$, Alp Ozgun BORCEK ${ }^{1}$, Cagatay GUVEN¹, Askin Esen HASTURK² \\ ${ }^{1}$ Batman State Hospital, Department of Neurosurgery, Batman, Turkey \\ ${ }^{2}$ Ankara Dr. Abdurrabman Yurtaslan Oncology Training and Research Hospital, Department of Neurosurgery, Ankara, Turkey
}

Correspondence address: Erkin SONMEZ / E-mail: erkinso@gmail.com

\begin{abstract}
Non-missile intracranial injuries caused by foreign bodies are quite uncommon in civilian practice. Nails, knives, screwdrivers and sewing needles are the most commonly reported agents. The authors report a unique case of an adult male patient who suffered a penetrating craniocerebral injury caused by a falling concrete reinforcing iron (rebar) from the fourth floor of a building under construction. The foreign body was safely removed by a right parietal craniectomy as a result of detailed radiological evaluation and preoperative planning. To the best of authors' knowledge, the successful surgical treatment of a penetrating brain injury caused by a rebar has not been reported previously.
\end{abstract}

KEYWORDS: Craniocerebral trauma, Penetrating, Foreign body

öz

Ateşli silahlar dışındaki yabancı cisimlerin neden olduğu penetran kafa travmaları sivil hayatta oldukça nadir görülürler. Çiviler, bıçaklar, tornavidalar ve dikiş iğneleri en çok suçlanan ajanlardır. Yazarlar, inşaatın dördüncü katından düşen demir bir çubukla yaralanan erişkin penetran beyin hasarı olgusu sunuyorlar. Yabancı cisim detaylı bir radyolojik değerlendirme ve cerrahi planlama ile sorunsuz çıkarılmış. Yazarlar literatürde yayınlanmış birçok penetran kafa travması olgusu bulunmasına rağmen, bu yayının inşaat demirinin neden olduğu ilk olgu olmasından ötürü ayrı bir önemi olduğunu öne sürmektedirler.

ANAHTAR SÖZCÜKLER: Kranioserebral travma, Penetran, Yabancı cisim

\section{INTRODUCTION}

Penetrating craniocerebral injuries, mainly caused by missiles are commonly seen in war situations $(1,2,5)$. Non-missile intracranial injuries caused by foreign bodies are quite rare in civilian practice. Nails, knives, screw-drivers, wood, fishing hooks, sewing needles, spear guns and barbeque skewers have been described as penetrating agents so far $(1,2)$. The vast majority of deaths from penetrating trauma are due to unintentional accidents while a significant minority follow suicides and homicides (2-5). Management of the penetrating head injuries can be complex since extensive surgical treatment can lead to significant morbidity and mortality in some patients. A detailed radiological investigation should be completed to identify the shortest and the safest route for the foreign body's removal (1-5). We report a unique case of a severe penetrating intracranial injury caused by a concrete reinforcing iron (rebar) which was fallen from the fourth floor of the building under construction.

\section{CASE REPORT}

An 18-year-old construction worker was admitted to our emergency unit with a rebar stuck into his head (Figure 1). On admission, the patient was fully conscious and cooperative. The rebar was embedded in the right parietal region close to the superior sagittal sinus at vertex level.
Neurological examination revealed left hemiplegia. Skull radiographs showed a hyperdense foreign material that penetrated from the right parietal region extending to the deep structures in an oblique fashion (Figure 2A,B). Cranial computerized tomography (CT) demonstrated a hyperdense lesion and edema around the right motor cortex. The extent of brain damage could not be ascertained on the CT images as a consequence of severe metallic artifacts (Figure 3). Antibiotics and antiepileptic prophylaxis were administered preoperatively. During the emergency surgery, a modified right parietal horseshoe scalp flap was made to expose the midline. Next, a right parietal craniectomy was performed while leaving an island of bone around the rebar to keep it stabilized. The superior sagittal sinus (SSS) was intact. The rebar was slowly removed under direct vision. The dural opening was enlarged. Hematoma and debris along the rebar tract was removed. Since the brain was edemateous, the bone flap was not put back. The skin flap was closed after duraplasty was performed with galeal graft. The postoperative course was uneventful. The motor strength was $4 / 5$ in his upper extremity and $2 / 5$ in his lower extremity on the postoperative first week. Control CT and CT angiography (CTA) did not reveal any pathology. No infection was observed during the followup period. Cranioplasty was performed on the postoperative sixth month. 


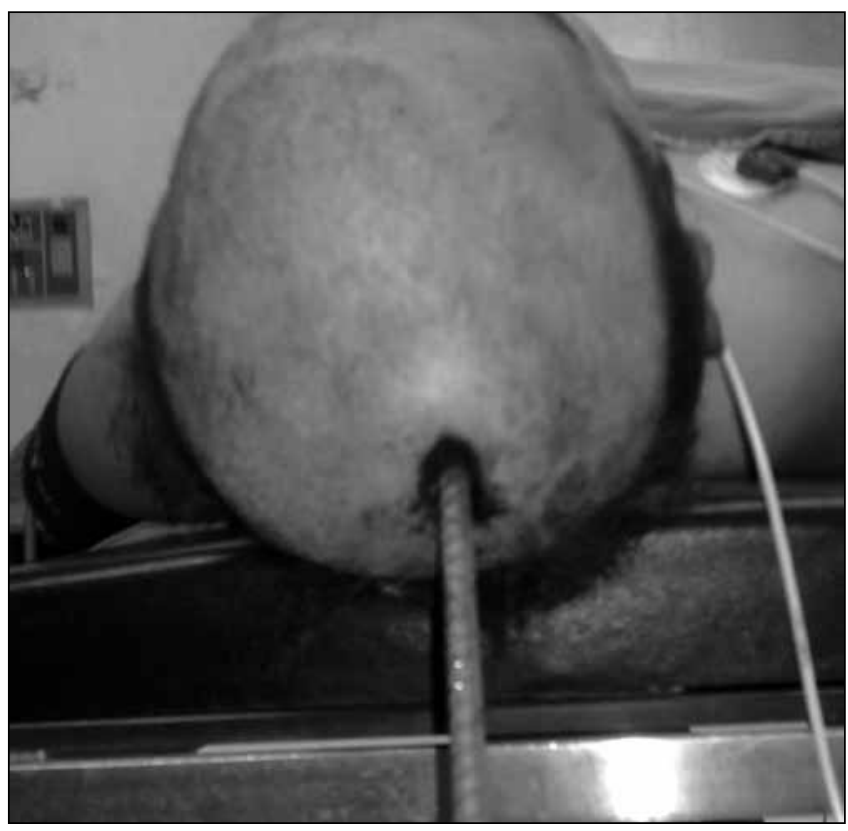

Figure 1: The rebar is embedded on the right parietal region close to the superior sagittal sinus at vertex level.

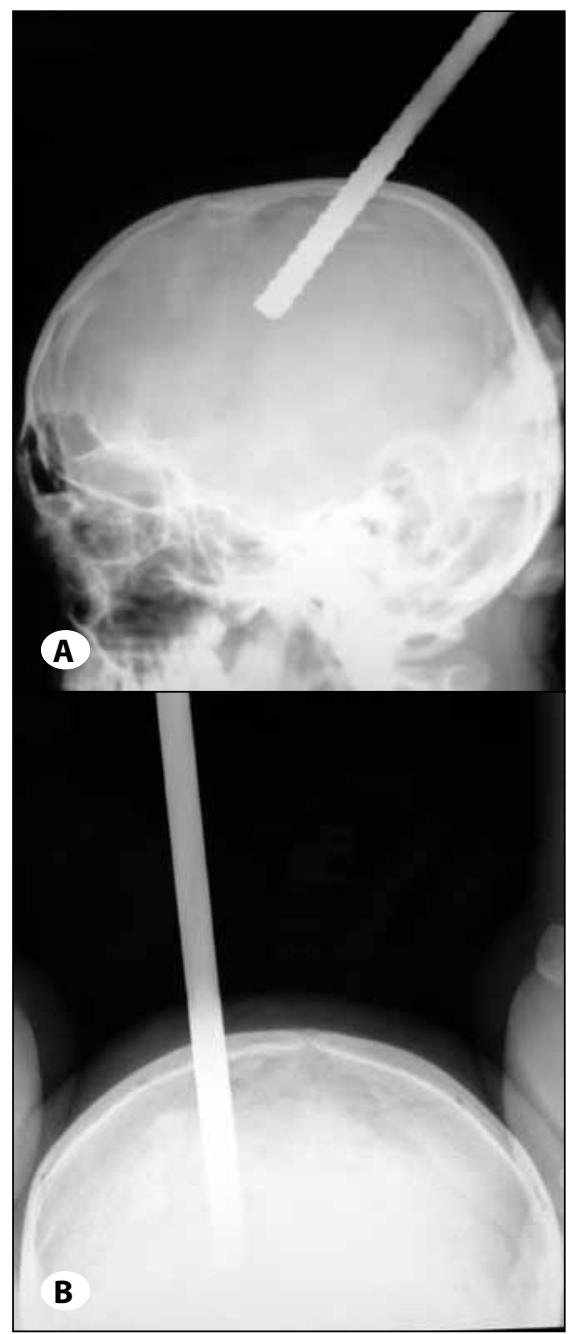

Figure 2: Lateral (A) and AP (B) X-rays showing a hyperdense foreign material that penetrated from the right parietal region extending to the deep structures in an oblique fashion.

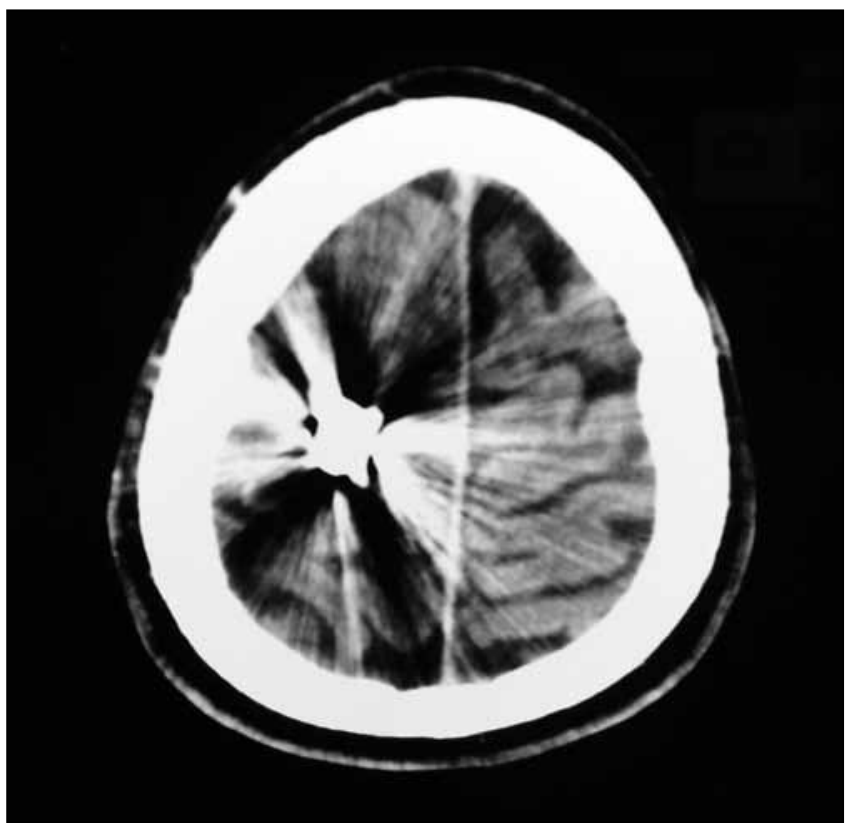

Figure 3: Cranial CT exhibiting a hyperdense lesion around the right motor cortex that causes metallic artifact.

\section{DISCUSSION}

Penetrating intracranial injuries caused by metallic foreign bodies are very rare among civilians. A detailed preoperative radiological study is needed for determining the safest route for the removal of foreign body (1-5). Skull X-rays are useful but not mandatory. CT scans are the mainstay of the radiological study. If vascular injury is suspected, CTA can be a good option and alternative to the conventional cerebral angiography $(2,5)$. Even if the first scan is negative, it would be better to repeat the scan two or three weeks later in order to diagnose pseudo-aneurysms. When a nonmagnetic object is suspected, a magnetic resonance imaging (MRI) scan may be superior to $C T(2,5)$.

Cranial infections after brain injuries are common and are also associated with high morbidity and mortality. Prophylactic antibiotic treatment should be started as soon as possible $(1,2)$. Regarding our antibiotic policy, we start antibiotics covering gram negative organisms and anaerobes. These antibiotics are continued for a period of two weeks and are changed if necessary according to the results of the microbiology tests. In the present case, antibiotics were ceased at two weeks since microbiological cultures were negative and the patient did not experience any fever.

Seizures may develop in about $30-50 \%$ of patients suffering a brain injury (1). Prophylactic antiepileptic treatment is controversial $(1,2,5)$. We routinely administer antiepileptics in penetrating brain injury cases. However, Chibbaro et al reported that they had not used prophylactic anticonvulsant therapy and none of their patients had developed epilepsy at a longest follow up of 13 years (2). 
Prompt neurosurgical intervention is recommended in patients suffering from penetrating brain injury with a reduced level of consciousness and/or focal motor deficit (1). The aim of the surgery is debridement of the necrotic brain tissue, removal of accessible bone or foreign body fragments, evacuation of hematomas that results in significant mass effect and closure of dural defects without aggravating neurological sequela (1-5). The question about the best technique, craniotomy vs. craniectomy, remains answerless. Statistically a significant difference was not reported between these two procedures by Rish et al. (6). In our case, since the rebar was located so close to the CNS, craniectomy was seen less risky to us not to harm the CNS. And also after the surgical exploration, the brain got swollen and it was not possible to put the bone flap back.

\section{CONCLUSION}

To the best of authors' knowledge, this is the first case reporting successful surgical treatment of a penetrating brain injury caused by a rebar. Construction workers should not be let to work without wearing helmets in order to avoid such accidents

\section{REFERENCES}

1. Cemil B, Tun K, Yigenoglu O, Kaptanoglu E: Attempted suicide with screw penetration into the cranium. Ulus Travma Acil Cerrahi Derg 15:624-627, 2009

2. Chibbaro S, Tacconi L: Orbito-cranial injuries caused by penetrating non-missile foreign bodies. Experience with eighteen patients. Acta Neurochir (Wien) 148:937-941, 2006; discussion 41-2

3. Farhadi MR, Becker M, Stippich C, Unterberg AW, Kiening KL: Transorbital penetrating head injury by a toilet brush handle. Acta Neurochir (Wien) 151:685-687, 2009

4. Mitilian D, Charon B, Brunelle F, Di Rocco F: Removal of a chopstick out of the cavernous sinus, pons, and cerebellar vermis through the superior orbital fissure. Acta Neurochir (Wien) 151:1295-1297, 2009

5. Pascual JM, Navas M, Carrasco R: Penetrating ballistic-like frontal brain injury caused by a metallic rod. Acta Neurochir (Wien) 151:689-691, 2009

6. Rish BL, Dillon JD, Caveness WF, Mohr JP, Kistler JP, Weiss GH: Evolution of craniotomy as a debridement technique for penetrating craniocerebral injuries. J Neurosurg 53:772-775, 1980 